\title{
MENILAI KESULITAN BELAJAR MATEMATIKA DENGAN PENGANTAR BAHASA INGGRIS MATERI LOGARITMA KELAS X BILINGUAL MA NEGERI 3 PALEMBANG
}

\author{
Sri wahyuni, M.Pd \\ MAN 3 Palembang, Kementerian Agama, Palembang \\ Yuyunmatondang072@gmail.com
}

Diterima: 27 Maret | Disetujui: 21 April | Dipublikasikan: 27 April

\begin{abstract}
ABSTRAK
Adanya kesulitan peserta didik dalam belajar matematika dengan pengantar bahasa Inggris pada materi Logaritma,sehingga penelitian ini bertujuan untuk mengetahui: (1) Kesulitan-kesulitan apa yang dialami peserta didik dan guru dalam belajar Matematika matei logaritma dengan pengantar bahasa Inggris pada program kelas bilingual, (2) Faktor-faktor apa yang menyebabkan peserta didik dan guru mengalami kesulitan dalam belajar Matematika dengan pengantar bahasa Inggris pada materi logaritma, (3) Upaya apa yang dilakukan untuk meminimalisasikan kesulitan yang dialami dalam belajar Matematika materi Logaritma dengan pengantar bahasa Inggris pada program kelas bilingual (CB). Penelitian ini menggunakan metode penelitian deskriptif kualitatif, yang dimaksud untuk mendescripsikan tentang kesulitan siswa dan guru dalam belajar Matematika materi logaritma dengan pengantar bahasa Inggris. Subyek penelitian adalah peserta didik kelas $X$ bilingual (cambridge) MA Negeri 3 Palembang. Sebagai sumber data adalah peserta didik dan guru yang diobservasi. Sebagai informan sumber data penelitian ini dipilih 10 orang peserta didik. Pengumpulan data dilakukan dengan 3 cara yaitu metode observasi, tesdan wawancara. Validasi data dilakukan dengan mengunakan triangulasi data yaitu dengan cara membandingkan 3 data yang ada; data hasil observasi, hasil tes dan data hasil wawancara.Dalam menganalisis data penelitian ini menggunakan analisis data kualitatif yang meliputi tahap reduksi data, penyajian data dan penarikan kesimpulan. Hasil penelitian ini ditemukan beberapa faktor kesalahan yang menyebabkan kesulitan peserta didik dan guru dalam belajar Matematika materi logaritma dengan pengantar bahasa Inggris pada kelas bilingual. Kesulitan-kesulitan itu adalah ketidakbenaran dalam menerima informasi yang disebabkan oleh kurang teliti, kegagalan dalam konsep Logaritma hal ini terjadi karena siswa lebih suka menghafal rumus, motivasi belajar Matematika peserta didik yang umumnya rendah, pengetahuan dan kemampuan prasyarat peserta didik yang cendrung kurang, kurangnya buku referensi matematika berbahasa Inggris, kemampuan berbahasa Inggris perserta didik yang menyebabkan guru sulit berkomunikasi. Diharapkan guru pelajaran Matematika lebih menekankan pemahaman konsep dan pengetahuan prasyarat, serta adanya peningkatan kemampuan berbahasa inggris yang dimiliki guru dan peserta didik.
\end{abstract}

Kata Kunci : Menilai kesulitan, Kelas bilingual, Pembelajaran Matematika, Bentuk logaritma. 


\begin{abstract}
[ASSESSING THE DIFFICULTIES OF LEARNING MATHEMATICS IN LOGARITHM WITH ENGLISH INTRODUCTION IN X BILINGUAL CLASS STATE ISLAMIC 3 OF PALEMBANG] There are dificulties for students in learning Mathematics in logarithmic with the intriduction of English. The purpose of this research was to determine: (1) what difficulties are experienced by students and teachers in learning mathematics on main subject of the logarithmic form with the introduction of English in the bilingual class program(CB), (2) What factors cause students and teachers have difficulties in learning Mathematics with the introduction of English on the subject matter of the logarithmic form, (3) what efforts are made to minimize the difficulties experienced in learning mathematics with the intoduction of English in the logarithmic form main immersion class program. This study used a qualitative descriptive method, the research subjects were students of class $X$ bilingual (cambridge) MA Negeri 3 of Palembang. As the data source was the observed teacher. From these data source 10 informant. Data collection was carried out by observation, test and interview methods. Data validation are carried out by data triangulation, namely by comparing observation data, test results and interview data. The data analysis includes the stages of data reduction, data presentation and conclusion. The result of this study found several error factors that cause of difficulties for students and teacher in learning mathematics with logarithmicwith the introduction of English in the bilingual class. These difficulties are incorrection of English in the bilingual class. These difficulties are the incorrectness in receiving information caused by in accurancy,failur in the logarithmic concept, its accour because student prefer to memorize formulas, students' motivation to learn Mathematic is generally low, the knowledge andprerequisite abilities of students are less, the lack of books English Math references, students English proficiency which causes teacher to have difficulty communicatin. It's hoped that Mathematics teachers will emphasize understanding concepts and prerequisite knowledge, as well as an increase in the English language skill possessed by teachers and students.
\end{abstract}

Key words : judge difficulty, bilingual class, mathematics, logarithmic

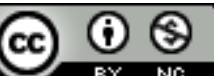




\section{PENDAHULUAN}

Pendidikan nasional bertujuan untuk mengembangkan dan meningkatkan mutu pendidikan yang membentuk watak serta peradaban bangsa yang bermartabat. Hal ini dilakukan dalam rangka mencerdaskan kehidupan bangsa dan mengembangkan manusia Indonesia seutuhnya sesuai yang tertuang dalam pembukaan UUD 1945, sebagai rujukan dasar pelaksanan pendidikan nasional di Indonesia.

Pendidikan merupakan proses sebuah kegiatan yang disengaja dimana input peserta didik dapat menimbulkan suatu hasil yang di inginkan sesuai tujuan yang di tetapkan. Sebagai sebuah proses yang disengaja, maka pendidikan harus dievaluasi hasilnya untuk melihat apakah hasil yang dicapai sudah sesuai dengan tujuan yang diinginkan dan apakah proses yang dilakukan efektif untuk mencapai hasil yang merupakan suatu pengharapan.

Pendidikan adalah suatu proses investasi jangka panjang yang memerlukan usaha dan dana yang cukup besar, hal ini diakui oleh semua orang tua atau pun suatu bangsa dan pengembang pendidikan demi kelangsungan hidup dan masa depannya. Demikian pula halnya dengan bangsa Indonesia menaruh harapan besar terhadap pendidik dalam hal ini guru, dalam perkembangan masa depan bangsa ini. Karena dari sanalah tunas muda harapan bangsa sebagai generasi muda terbentuk. Sudah kita ketahui bahwa pendidikan adalah suatu proses investasi jangka panjang yang harus ditata, disiapkan dan di beri sarana dan prasarana dalam arti memerlukan modal material yang cukup besar, akan tetapi sampai saat ini Indonesia masih berkutat pada problematika permasalahan klasik dalam hal ini adalah kualitas pendidikan, permasalahan ini bagaikan sebuah mata rantai yang melingkar dan tidak tahu dimana mesti diawali.

Terkait dengan mutu pendidikan itu pendidikan pada jenjang madrasah aliyah negeri (MAN) khususnya Madrasah Aliyah Negeri 3 Palembang kini membuka program bilingual (CB). Dimana program ini mengunakan pengantar bahasa inggris pada pembelajaran Matematika dan IPA. Program ini bertujuan menjawab semua permasalahan mutu pendidikan di Indonesia baik dalam bidang IImu Pengetahuan, Teknologi (IPTEK) dan bahasa.

Perkembangan Ilmu Pengetahuan dan Teknologi (IPTEK) serta globalisasi dan informasi dewasa ini yang kian pesat, membutuhkan Sumber Daya Manusia (SDM) yang berkualitas, yang mampu dan siap berkompetisi baik di dalam negeri maupun di kancah persaingan bebas dunia. Sekolah sebagai tempat penyelenggaraan pendidikan yang efektif dan bermutu memiliki peran yang strategis dalam mewujudkan manusia Indonesia yang berkualitas.

Untuk itu dalam membangun kerangka dan sistem pendidikan Indonesia di masa depan, tidak hanya semata-mata sekedar bagaimana mencapai tujuan pembelajaran saja, melainkan perlu juga memperhatikan keterkaitan-keterkaitan antara pengembangan potensi manusia secara pribadi dengan kehidupannya dimasyarakat secara utuh. Sehingga selaras dengan tuntutan perkembangan 
zaman baik pada lingkungan lokal, nasional, regional dan internasional.

Hal ini menuntut guru untuk dapat berperan aktif dalam mempersiapkan tunas bangsa yang berkualitas. Ini dikarenakan fungsi guru adalah seorang pendidik, pembimbing, pelatih dan pengembang kurikulum yang dapat menciptakan kondisi dan suasana belajar yang menyenangkan, menarik dan memberi rasa aman, memberi ruang kepada siswa untuk berpikir aktif, kreatif dan inovatif dalam mengeksplorasi kemampuannya (Asmani,2009).

Untuk itu faktor guru sangat berpengaruh terhadap kelangsungan proses kegiatan belajar mengajar. Keberhasilan proses pembelajaran tidak dapat lepas dari peran guru sebagai garda terdepan dalam pendidikan. Guru dituntut untuk melaksanakan tugasnya dengan profesional, yang memiliki empat kompetensi yaitu kompetensi keperibadian, kompetensi pedagogik, kompetensi profesional dan kompetensi sosial. Keempat kompetensi itu di harapkan mampu mengaplikasikan berbagai teori belajar di bidang pengajaran, mampu memilih dan menerapkan metode pengajaran yang efektif dan efisien, mampu melibatkan peserta didik berpartisipasi aktif dan mampu menciptakan suasana belajar yang menyenangkan guna menunjang tercapainya tujuan pendidikan, sehingga problematika pendidikan yang di hadapi bangsa Indonesia dalam rendahnya mutu pendidikan dapat diatasi.

Melihat kondisi saat ini akan rendahnya mutu pendidikan dan menyadari bahwasanya pentingnya bahasa Inggris yang merupakan bahasa internasional, maka muncul ide atau gagasan tentang program kelas bilingual (CB). Seperti kita ketahui bahwa kemampuan bilingualitas suatu bangsa merupakan fenomena yang perlu mendapat perhatian karena tingkat dapat menjadi tolak ukur ketangguhan bangsa tersebut dalam kiprah dikancah internasional. Hal ini lah yang menjadi salah satu alasan Madrasah Aliayah Negeri (MAN) 3 Palembang dalam pelaksanaan program kelas bilingual, namun masih adanya keraguan sebagian masyarakat yang mempertanyakan terhadap efektivitas pembelajaran program kelas bilingual yang diterapkan di Madrasah Aliyah Negeri 3 (MAN) Palembang. Keraguan muncul atas dasar beberapa pemikiran, kurangnya penguasaan bahasa Inggris bagi peserta didik sebagai bahasa pengantar dalam pembelajaran, siswa mempunyai beban ganda yaitu penguasaan bahasa Inggris sebagai bahasa pengantar dalam pembelajaran dan pencapaian kompetensi dasar. Mengingat beban biaya yang ditanggung orang tua siswa program kelas bilingual (CB) cukup besar jika dibandingkan dengan program kelas regular, sedangkan hasil belajar yang akan dicapai masih belum terlihat jelas. Para lulusan program bilingual (CB) diharapkan bisa mengatasi kendalakendala kebahasaan pada saat kontak internasional sehingga mereka bisa berkomunikasi, bernegosiasi, berargumentasi dan sebagainya dengan bangsa lain dengan baik.

Dalam proses belajar mengajar dan hasil belajar peserta didik sebagian besar di tentukan oleh peran dan kompetensi guru di berbagai macam hal, baik teknik mengajar yang dapat di kembangkan seorang guru dalam mencapai tujuan 
pembelajarannya, keaktifan, inovatif, kreatif, efektif dan menyenangkan. Jadi peran guru sangat lah penting dalam memacu semangat siswa dalam proses pembelajaran, apalagi di kelas bilingual (CB) yang membutuhkan teknik dan model mengajar ekstra aktif, kreatif dan inovatif. Model PAIKEM sendiri adalah suatu pendekatan terbaru dalam pembelajaran yang berorientasi kepada kreatifitas guru dan pengguna media yang variatif dan inovatif (Ngalimun, 2016). Karena pada program kelas bilingual, proses pembelajaran menggunakan pengantar bahasa Inggris meliputi mata pelajaran Matematika, Fisika, Kimia, Biologi, bahasa Inggris, Ekonomi, Sejarah dan Geografi hal ini yang menuntut guru mengunakan media dan model pembelajaran yang variatif dan inovatif. Dalam hal ini penulis memfokuskan penelitiannya pada pembelajaran Matematika. Dapat dijelaskan bahwasanya Matematika adalah salah satu pelajaran yang dianggap sulit bagi siswa baik di program reguler apalagi pada siswa di program bilingual (CB). Adapun materi pelajaran Matematika yang diajarkan di kelas $X$ yaitu: bentuk akar pangkat dan logaritma, persamaan dan fungsi kuadrat, sistem persamaan linear, pertidaksamaan dan kuadrat.

Menurut pengamatan penulis ketika materi baru sampai pada bentuk pangkat dan akar, siswa tidak terlalu mengalami kesulitan karena saat duduk di Sekolah Menengah Pertama (SMP/ MTs), peserta didik sudah menempuh materi bentuk pangkat dan akar. Namun, saat materi sudah mulai masuk ke bentuk logaritma, siswa mulai merasa kesulitan apalagi materi tersebut merupakan materi yang baru dikenal oleh peserta didik. Kesulitan-kesulitan yang dialami peserta didik dapat terjadi karena peserta didik kurang menguasai konsep logaritma. Berdasarkan daftar nilai semester 1 kelas $X$ (CB)atau X IPA 9 (bilingual) tahun ajaran 2019/2020, dari 31 orang peserta didik 13 laki-laki dan 18 perempuan yang mengikuti tes ulangan harian $(\mathrm{PH})$ pokok bahasan logaritma terdapat 56\% dari jumlah peserta didik tidak mencapai nilai Kriteria Ketuntasan Minimal (KKM) pada pelajaran Matematika. Menurut guru bidang studi Matematika, penguasaan peserta didik pada materi pokok bentuk logaritma tergolong rendah. Untuk membantu mengatasi permasalahan yang dihadapi peserta didik dalam pembelajaran Matematika terutama dalam memahami konsep logaritma yang disampaikan dengan pengantar bahasa Inggris, perlu dicari penyebab dari permasalahan peserta didik tersebut sehingga di temukan kunci penyelesaian masalah tersebut.Faktor-faktor penyebab kesulitan peserta didik dalam belajar antara lain: faktor dari peserta didik itu sendiri meliputi minat, tingkat kemampuan intelligence, kebiasaan belajar, motivasi belajar, konsentrasi (Fauziah, 2017) selanjutnya bahwa faktor -faktor yang mempengaruhi kesulitan belajar matematika adalah faktor yang bersumber dari diri sendiri, faktor-faktor yang bersumber dari lingkungan sekolah, faktor-faktor yang bersumber dari lingkungan masyarakat malik, (Hamalik,1983. Jadi sangat jelas, faktor sekolah meliputi ; Guru, Suasana sekolah, Perpustakaan selain itu faktor keluarga meliputi; Kurangnya perhatian orang tua pada pendidikan anaknya, Suasana lingkungan rumah yang ramai atau 
gaduh tidak mungkin membuat peserta didik akan dapat belajar dengan tenang

Pemerintah melalui Direktorat Pendidikan Lanjutan Pertama, Direktorat Jenderal Pendidikan Menengah Umum (Direktorat Pendidikan Dasar dan Menengah) Kementerian Pendidikan dan Kebudayaan (Kemendikbud) memprogramkan untuk melakukan implementasi Mathematics and science in English. Program ini di mulai pada tahun pelajaran 2004/ 2005 di 31 sekolah koalisi tingkat SMP dan SMA di 30 provinsi di Indonesia. Program Mathematics and Science in English terbatas pada pengajaran Matematika dan IPA dalam bahasa Inggris atau disebut Immersion class atau kelas imersi. Model pembelajaran kelas imersi/ bilingual (CB) didefinisikan sebagai penyampaian kurikulum dengan bahasa kedua (L2) bahasa Inggris dalam lingkungan pembelajaran berbahasa kedua pada siswa yang memiliki bahasa ibu (L1) yang sama.

Dalam hal ini peserta didik dimasukkan dalam lingkungan bahasa kedua untuk pembelajaran dan mata pelajaran berbahasa ke 2 (L2) dalam proses pembelajaran. Bahasa kedua berfungsi tidak hanya sebagai materi pengajaran saja tetapi juga sebagai alat pengajaran dan perolehan bahasa (Luan $\&$

Guo,2011ttp://proquest.umi.com/pqdwe b). Dalam program ini bahasa Inggris bukan sebagai mata pelajaran semata tetapi sebagai bahasa pengantar dalam proses pembelajaran mata pelajaran lainnya, UU No 20 Tahun 2003 tentang Sistem Pendidikan Nasional BAB VII pasal 33 ayat (3) yang berbunyi "Bahasa asing dapat digunakan sebagai bahasa pengantar pada satuan pendidikan tertentu untuk mendukung kemampuan berbahasa peserta didik".

Sekolah-sekolah penyelenggara program pembelajaran Matematika dan Ilmu Pengetahuan Alam dengan pengantar bahasa Inggris diharapkan memfokuskan kegiatannya pada aspekaspek berikut agar mencapai tujuan pembelajaran (1) Pengembangan materi pelajaran berbahasa Inggris Pengembangan media pembelajaran (3) Peningkatan kompetensi guru dalam bahasa Inggris (4) Pembiasaan pengunaan bahasa Inggris di sekolah (5) Penerapan sistem Manajemen Berbasis Sekolah dan kepemimpinan sekolah secara konsisten (Budiyono,2003).

Rumusan masalah penelitian ini, yaitu "Apakah faktor-faktor kesulitan yang dialami peserta didik dan guru dalam pembelajaran Matematika materi pokok bentuk Logaritma dengan pengantar Bahasa Inggris pada kelas $X$ bilingual (CB) MAN 3 Palembang ?"

\section{METODE PENELITIAN}

Penelitian ini merupakan penelitian kualitatif. Peneltian kualitatif adalah suatu penelitian yang ditujukan untuk mendiskripsikan dan menganalisis fenomena, peristiwa, aktivitas sosial, sikap, kepercayaan, persepsi, pemikiran orang secara individual dan kelompok. Penelitian ini, tidak menggunakan hipotesis dan data. Data tersebut adalah data deskriptif yang berupa kata-kata tertulis atau lisan. Penelitian ini mengkaji bentuk karakteristik, aktifitas, perubahan, hubungan,kesamaan dan perbedaannya matematika dengan fenomena lain (Kartono, 1985). Penelitian deskriptif 
tidak memberikan perlakuan tetapi menggambarkan kondisi yang berjalan sebagaimana adanya.

Penelitian ini menggunakan teknik sampel. Penelitian ini dilakukan pada siswa kelas X CB MA Negeri 3 Palembang dengan jumlah peserta didik 31 orang terbagi atas 13 orang peserta didik lakilaki dan 18 orang peserta didik perempuan tahun ajaran 2019/2020. Kemudian dipilih beberapa peserta didik yang mewakili masing- masing kelompok dari jenis kesalahan yang dilakukan untuk diwawancara dan dianalisis datanya.

Penelitian ini menggunakan metode observasi, yaitu untuk melihat dan mengamati sendiri, kemudian mencatat perilaku dan kejadian sebagaimana yang terjadi pada keadaan yang sebenarnya (Lexy,2000), selanjutnya penelitian ini menggunakan metode tes yang berbentuk soal-soal uraian yangn tujuannya untuk mengetahui kesalahankesalahan yang dilakukan siswa dalam menyelesaiankan soal dan metode wawancara untuk memperoleh informasi tentang proses pembelajaran (Nana,2009)

Salah satu cara untuk mendapatkan kevalidan data pada penelitian kualitatif ini adalah dengan triangulasi. Trianggulasi adalah teknik pengumpulan data yang bersifat mengabungkan dari berbagai teknik pengumpulan data dan sumber data yang telah ada sekaligus menguji kredibilitas data (Sugiyono, 2009). Triangulasi data yang digunakan dalam penelitian ini adalah triangulasi metode. Triangulasi metode dalam penelitian ini dilakukan dengan cara membedakan data-data yang dikumpulkan dengan metode observasi, tes dan wawancara terhadap subjek penelitian.

\section{TEMUAN DAN PEMBAHASAN}

\section{Temuan}

Dari hasil penelitian ditemukan beberapa hal kesalahan yang menyebabkan kesulitan peserta didik dalam pembelajaran Matematika materi logaritma dengan pengantar bahasa Inggis,. Kesalahan-kesalahan tersebut yaitu ketidakbenaran dalam menerima informasi yang disebabkan kurang telitinya peserta didik membaca soal, peserta didik juga tidak menghiraukan bentuk akar dan pangkat yang ada di dalam soal karena mereka tidak terbiasa dengan soal yang mengandung unsur bentuk akar dan pangkat. Kegagalan dalam mengonsep bentuk logaritma umumnya terjadi karena peserta didik lebih suka mempelajari materi pada bagian rumus dan langkah-langkah penyelesaian soal dari pada mempelajari konsep-konsep yang terkandung dalam definisi bentuk logaritma tersebut. Kegagalan dalam menentukan strategi, peserta didik gagal dalam menentukan strategi, peserta didik gagal dalam menggunakan prosedur dan langkahlangkah untuk menyelesaikan soal. Kegagalan mengambil langkah yang dilakukan menyebabkan peserta didik mengalami jalan buntu saat mengerjakan soal yang diberikan. Menggunakan prosedur dan langkah-langkah untuk menyelesaikan soal. Kegagalan mengambil langkah yang dilakukan menyebabkan peserta didik mengalami jalan buntu saat mengerjakan soal yang diberikan. Peserta didik hanya mengerjakan setengah jalan sehingga peserta didik tidak menemukan hasil 
akhir yang ditanyakan pada soal. Hal ini dapat terjadi karena peserta didik kurang dalam melakukan latihan latihan soal.

Kekurang telitian peserta didik menyebabkan peserta didik melakukan kesalahan dalam menghitung. Hal ini terjadi karena peserta didik kurang dalam melakukan latihan-latihan soal. Selain itu Kesalahan pada penulisan pada materi Logaritma terjadi karena peserta didik kurang teliti dan terburu-buru saat mengerjakan soal. Terdapat juga beberapa orang peserta didik yang tidak mengetahui posisi penulisan yang tepat dari bilangan pokok, karena peserta didik tidak memahami dari keterangan definisi Logaritma yang ada. Peserta didik menganggap bilangan pokok dan numerus itu sama dalam letak penulisan. Selain itu penulis juga menemukan beberapa masalah yang datang dari guru mata pelajaran khususnya Matematika.

Temuan ini diperoleh melalui wawancara yang dilaksanakan dengan guru mata pelajaran Matematika pada tanggal 20-21 November 2019, diperoleh hasil, bagi guru salah satu kendala yang dirasakan adalah motivasi belajar Matematika peserta didik secara umum tergolong rendah, sehingga menyebabkan guru sulit menggunakan berbagai cara mengelola pembelajaran secara kreatif, karena biasanya dalam hal ini menuntut motivasi belajar yang tinggi dari peserta didik. Pengetahuan dan kemampuan prasyarat yang dimiliki oleh peserta didik dalam mempelajari materi pokok bentuk Logaritma cenderung kurang. Oleh karena itu, guru perlu mengulang kembali materi prasyarat yang diperlukan sebelum memulai pembelajaran tentang materi pokok bentuk Logaritma. Hal ini cenderung membuat guru menyita banyak waktu yang seharusnya bias dipakai untuk melaksanakan program pembelajaran yang telah direncanakan. Kurangnya buku-buku referensi. Selain itu Kurangnya buku-buku referensi matematika berbahasa Inggris tingkat SMA/MA yang bisa digunakan oleh guru Matematika. Dari segi bahasa pengantar pada pembelajaran Matematika yaitu bahasa Inggris yang digunakan dalam proses pembelajaran, kemampuan peserta didik dalam penguasaan bahasa tersebut yang kurang menyebabkan guru mengalami kesulitan dalam menciptakan komunikasi yang baik di dalam kelas.

\section{Pembahasan}

Masalah yang muncul dapat di temukan pada beberapa faktor yang menyebabkan peserta didik mengalami kesulitan belajar matematika materi logaritma dengan pengantar bahasa inggris diantaranya penguasaan bahasa, kebiasan dan pendekat cara belajar, minat yang berbeda antara peserta didik yang satu dengan peserta didik yang lainnya sehingga, perbedaan mendasar itu menjadikan penyebab utama dalam belajar matematika khususnya materi logaritma dengan pengantar bahasa Inggris

Pelaksanan menilai kesulitan belajar dilakukan dengan mengunakan cara yang dapat di tempuh dalam proses menilai kesulitan belajar adalah dengan menindentifikasi adanya kesulitan belajar, menelaah dan memperkirakan sebab terjadinya kesulitan belajar. Selain itu menilai kesulitan belajar dapat pula dilakukan melalui observasi dan wawancara dengan guru mata pelajaran maupun dengan siswa. Berdasarkan hasil observasi dan wawancara, diperoleh 
informasi bahwa peserta didik tidak mau bertanya kepada guru apabila mereka mengalami kesulitan. Karena mereka lebih senang bertanya kepada teman daripada kepada guru. Alasan yang diungkapkan bervariasi diantaranya malu dan takut. Mereka takut diminta mengerjakan soal di depan. Kurangnya motivasi siswa dalam mengerjakan tugas yang diberikan guru, hal ini yang menyebabkan mereka tidak mau mencoba mengerjakan soal tetapi lebih mengandalkan pembahasan jawaban yang dilakukan bersama-sama.

Hasil menilai kesulitan belajar ini dapat juga dimanifestasikan pula oleh guru sesuai dengan hasil menilai kesulitan belajar Matematika dalam bentuk logaritma dengan pengantar bahasa Inggris yang menyatakan bahwa nilai rata-rata siswa dibawa KKM artinya pelaksanaan menilai kesulitan belajar peserta didik pada kelas program bilingual MAN 3 Palembang dalam katagori tinggi, hal ini menuntut guru matematika pada kelas program bilingual harus berperan aktif dalam peningkatan kemampuan siswa khususnya kelas bilingual.

Bentuk kesulitan yang berasal dari faktor intern adalah hal-hal atau keadaan yang ada dari dalam diri peserta didik itu sendiri meliputi cara belajar, minat, motivasi dan intelektual sedangkan faktor eksternal yakni halhal atau keadaan yang datang dari luar diri peserta didik meliputi situasi dan kondisi lingkungan dan keluarga misalnya kurangnya referensi buku matematika dengan bahasa pengantar bahasa Inggris serta kurangnya dukungan orang tua. Selain itu Proses pembelajaran Matematika di kelas sangat mempengaruhi peserta didik dalam memahami konsep yang ada pada materi pokok bentuk Logaritma. Kesepuluh subjek penelitian mengaku bahwa perhatian mereka terhadap proses pembelajaran di kelas sangatlah kurang. Alasan yang dikemukakan peserta didik tersebut sangatlah bervariasi diantaranya materi ajar yang sulit dipahami karena merupakan materi baru yang diterima peserta didik dan bentuk penyajian materi yang disampaikan guru kurang menarik.

Mereka terbiasa dengan cara belajar Matematika hafalan, mereka jarang latihan mengerjakan soal. Cara belajar yang dilakukan peserta didik ini bukanlah cara belajar yang baik. Apabila mereka gagal dalam mengingat rumus dan prosedur yang mereka hafal, maka tidak akan terjadi keberhasilan dalam menyelesaikan soal. Sejalan dengan Setyabukti (dalam Handayani, 2015) masih menekankan pada menghafal rumus dan menghitung hal ini menyebabkan pemahaman konsep siswa kurang. Hai ini bisa dilihat ketika peserta didik mengerjakan soal-soal yang diberikan di MA yang sangat berbeda dengan soal yang diberikan di SMP/MTs. Salah satu subjek penelitian ini adalah tidak belajar sebelum mengerjakan soalsoal yang diberikan. Oleh karena itu, kesalahan yang dilakukan peserta didik yang lain, subjek tidak menerapkan konsep yang dipelajari saat proses pembelajaran untuk menyelesaikan soal, selajutnya kegiatan belajar mengajar yang menggunakan pengantar bahasa Inggris juga menyulitkan peserta didik untuk menangkap dan memahami materi pokok bentuk Logaritma secara sempurna. Kesepuluh subjek penelitian 
yang memiliki kemampuan berbahasa Inggris kurang mengaku bahwa banyak materi yang mereka tidak mengerti, karena tidak semua peserta mengikuti kursus bahasa Inggris di luar jam sekolah untuk meningkatkan kemampuan berbahasa Inggris.

Peserta didik hanya mengandalkan kemampuan bahasa Inggris seadanya untuk mengikuti proses pembelajaran di kelas. Walaupun terkadang guru menggunakan pengantar bahasa Indonesia, peserta didik masih merasa kesulitan untuk memahami materi yang diajarkan. Susunan kalimat yang digunakan guru terkadang campuran antara bahasa Inggris dan bahasa Indonesia juga menyulitkan peserta didik untuk lebih memahami materi bentuk logaritma.

Mencermati hasil data menilai tentang kesulitan belajar Matematika peserta didik kelas $\mathrm{X}$ program bilingual MAN 3 Palembang diperoleh gambaran tentang kesulitan belajar Matematika peserta didik pada materi Logaritma bahwa terdapat beberapa faktor penyebab kesulitan sehingga mengharuskan guru Matematika harus menyikapi masalah-masalah yang muncul tersebut untuk membantu peserta didik keluar dari kesulitan belajar yang di alaminya sebagaimana yang diperoleh dari hasil penelitian.

Upaya yang dilakukan oleh guru Matematika khususnya pada kelas program bilingual untuk mengindentifikasi kesulitan belajar dan selanjutnya memberikan penanganan sesuai kebutuhan peserta didik untuk mengatasi kesulitan belajar peserta didik, sehingga perbaikan belajar merupakan satu rangkaian kegiatan pembelajaran merupakan satu upaya untuk menciptakan lingkungan belajar mengajar

untuk mencapai tujuan yang telah ditetapkan jadi proses belajar di kelas sangatlah mempengaruhi peserta didik dalam memahami materi pelajaran.

Sajian materi yang menarik perhatian peserta didik akan sangat bermanfaat terutama bagi peserta didik yang mempunyai motivasi dan minat belajar yang rendah. Hal ini sesuai dengan pendapat (Ahmadi \& Supriyono, 2013) bahwa " tidak adanya minat seorang anak terhadap suatu pelajaran akan timbul kesulitan belajar. Dimana kita tahu bahwa motivasi belajar merupakan salah satu aspek yang sangat penting sekali dalam menentukan prilaku seseorang termasuk prilaku dalam belajar, di samping itu motivasi belajar juga di pengaruhi oleh lingkungan belajar yang terstruktur dengan baik. Hal ini terlihat, bahwa peserta didik yang duduk di belakang mengaku tidak dapat membaca tulisan di papan tulis dan mendengar suara guru dengan jelas sehingga peserta didik tidak dapat memperhatikan proses pembelajaran dengan baik. Lain hal pada proses pembelajaran di kelas yang mempengaruhi peserta didik dalam tingkat pemahaman konsep adalah tidak adanya penekanan pada penarikan kesimpulan, baik oleh guru maupun dari peserta didik itu sendiri.

Penarikan kesimpulan terhadap materi yang dipelajari merupakan hal yang sangat penting karena dapat menghilangkan atau meminimalisir keraguan atas pemahaman konsep,karena kemampuan pemahaman konsep merupakan suatu kemampuan 
untuk menguasai makna suatu pokok bahasan secara luwes akurat efisien dan tepat.

Media pembelajaran, hanya berfungsi sebagai alat bantu guru untuk mengajar, sekitar pertengahan abad ke20 usaha pemanfaatan visual dilengkapi dengan audio di gunakan di dunia pendidikan sebagai media pembelajaran. Sejalan dengan perkembangan ilmu pengetahuan dan teknologi (IPTEK) saat ini penggunaan alat bantu atau media pembelajaran menjadi semakin luas dan interaktif, seperti adanya komputer dan internet. Madrasah Aliyah Negeri 3 Palembang dalam hal ini juga berupaya menyiapkan media pembelajaran yang dapat mendukung kelancaran proses belajar mengajar di program kelas bilingual (CB).

Media pembelajaran yang telah disediakan pihak sekolah untuk menunjang pembelajaran adalah komputer, LCD, Layar LCD dan bukubuku pedoman penunjang belajar untuk kelas bilingual (CB). Diharapkan peserta didik dapat memanfaatkan media tersebut. Sehingga guru dapat memanfaatkan secara optimal komputer, LCD dan layarnya yang membuat proses pembelajaran akan lebih menarik. Bukubuku pedoman penunjang pembelajaran kelas bilingual di perpustakaan juga dapat dimanfaatkan dengan baik oleh peserta didik. Peserta didik mau mencoba latihan-latihan soal tambahan menggunakan buku pedoman tersebut untuk menambah pengalaman menghadapai soal-soal yang variatif. Selain itu, penyampaian materi pelajaran atau bahan ajar merupakan salah satu kegiatan dan proses belajar mengajar yang harus didesain sebaik mungkin.
Bahan ajar adalah segala bentuk bahan atau materi yang disusun secara sistematis yang digunakan untuk membantu guru dalam melaksanakan kegiatan belajar mengajar sehingga tercipta lingkungan atau suasana yang memungkinkan peserta didik untuk belajar. Dengan kata lain bahwa, bahan ajar adalah alat teks yang digunakan guru untuk menyampaikan informasi guna perencanaan dan penelahaan implementasi pembelajaran.

Selain proses pembelajaran di kelas, cara belajar peserta didik juga dapat di perbaiki karena dapat mempengaruhi keberhasilan peserta didik dalam menyelesaikan soal-soal. Kesepuluh subjek penelitian mengatakan bahwa mereka lebih suka menghafal rumus dan prosedur menyelesaikan soal daripada memahami konsep yang ada. Mereka terbiasa dengan cara belajar Matematika hafalan, mereka jarang latihan mengerjakan soal. Cara belajar yang dilakukan peserta didik ini bukanlah cara belajar yang baik. Apabila mereka gagal dalam mengingat rumus dan prosedur yang mereka hafal, maka tidak akan terjadi keberhasilan dalam menyelesaikan soal.

Proses pembelajaran Matematika di kelas yang kurang memanfaatkan media pembelajaran yang disediakan pihak sekolah serta cara belajar peserta didik yang salah dapat menyebabkan ketidak pahaman atau kurangnya pemahaman bahkan ketidaktahuan peserta didik terhadap suatu konsep Matematika. Konsep itu sendiri merupakan penanda suatu pengetahuan, pengetahuan tanpa konsep bukanlah merupakan pengetahuan. Hal Inilah yang dapat menyebabkan mereka melakukan 
kesalahan dalam menyelesaikan soal Matematika baik kesalahan konsep maupun kesalahan penerapan konsep. Materi bentuk Logaritma merupakan hal yang baru bagi peserta didik pada jenjang MA kelas $X$. Hal inilah yang menyebabkan perserta didik sulit untuk menerima pengetahuan yang baru dan menyesuaikannya dengan pengetahuan lama.

Penyampaian materi oleh guru yang kurang menekankan pada pemahaman konsep dapat menyebabkan kesalahan konsep atau kesalahan penerapan konsep, hal ini terjadi karena lemahnya pemahaman konsep yang dimiliki peserta didik. Kemungkinan terjadinya kesalahan pada soal yang berbentuk aplikasi atau soal pemahaman suatu konsep sangatlah besar. Pembahasan soal dalam bentuk tersebut juga perlu dilakukan untuk meningkatkan kemampuan peserta didik dalam menyelesaikan soal-soal. Faktor lain yang tidak kalah penting dalam mempengaruhi peserta didik dalam menyelesaikan soal-soal yang berkaitan dengan bentuk Logaritma adalah pemahaman mereka akan materi prasyarat.

Lemahnya penguasaan materi prasyarat seperti konsep dalam aturan pencarian akar persamaan kuadrat, perhitungan bentuk pecahan dapat menyebabkan peserta didik melakukan kesalahan pada materi prasyarat. Belajar Matematika memang harus bertahap, peserta didik harus menguasai materi prasyarat yang dibutuhkan untuk mempelajari suatu materi.

Penguasa materi prasyarat merupakan salah satu tanda kesiapan peserta didik untuk mengikuti pelajaran materi Matematika selanjutnya. Konsep lanjutan sulit dipahami sebelum memahami dengan baik konsep sebelumnya yang menjadi prasyarat. $\mathrm{Hal}$ yang demikian ini lah yang tidak disadari oleh peserta didik yang disebabkan minimnya informasi mengenai apa dan bagaimana sebenarnya Matematika itu, sehingga akan menjadi suatu hal yang berakibat buruk bila peserta didik tidak menguasai dan memahami konsep dasar sebagai prasyaratnya. Dari kesulitankesulitan yang dialami peserta didik dan guru dalam melaksanakan proses pembelajaran Matematika dengan menggunakan pengantar bahasa Inggris pada materi bentuk Logaritma, maka perlu adanya upaya-upaya untuk meminimalisasikan kesulitan yang dialami sehingga dalam melaksanakan program kelas bilingual ( $C B$ ) ke depannya akan menjadi lebih efektif dan efisien dalam mencapai tujuan belajar.

Kesulitan yang dialami peserta didik dalam pemahaman materi bentuk Logaritma dapat diminimalisasikan dengan diadakannya jam tambahan di luar jam sekolah yang tujuannya untuk memperdalam materi pelajaran. Peserta didik juga harus mengatur waktu dan menyempatkan diri untuk mengikuti les di luar program sekolah, sehingga peserta didik memperoleh tambahan materi dan soal-soal yang lebih bervariasi. Selain kesulitan pada pemahaman materi, peserta didik dan guru juga merasa sulit dalam menciptakan komunikasi pembelajaran yang menggunakan pengantar bahasa Inggris, maka baik guru dan peserta didik perlu adanya bimbingan komunikasi berbahasa Inggris sehingga antara guru dan peserta didik saling memahami bahasa komunikasi yang digunakan. Agar 
guru dapat mengelola kelas dengan baik, maka guru perlu mengikuti diklat/kursus yang diprogramkan oleh Kementerian Agama dan sekolah sehingga guru mengetahui bagaimana cara penyampaian materi yang baik dengan mengunakan model-model pembelajaran yang menarik sesuai dengan kurikulum yang berlaku sehingga peserta didik termotivasi untuk belajar.

\section{SIMPULAN DAN REKOMENDASI}

\section{Kesimpulan}

Mengacu pada tujuan penelitian yang telah diuraikan, sehingga dapat disimpulkan beberapa hal mengenain kesulitan-kesulitan yang dialami peserta didik dalam pembelajaran Matematika materi pokok bentuk Logaritma dengan pengantar bahasa Inggris pada program kelas bilingual (CB) antara lain peserta didik melakukan kesalahan pada penerapan konsep, baik konsep bentuk Logaritma maupun konsep prasyarat terkait bentuk logaritma. Dalam hal ini peserta didik tidak dapat mencapai tingkat penguasaan yang diperlukan sebagai prasyarat untuk menyelesaikan soal terkait materi bentuk pokok Logaritma. Pada kasus ini, peserta didik di golongkan jenis kesulitan slow learners.

Kurangnya ketelitian peserta didik menyebabkan peserta didik tidak dapat menyelesaikan soal. Peserta didik paham dengan konsep untuk menyelesaikan soal terkait materi pokok bentuk Logaritma, tetapi tidak sesuai dengan jawaban yang benar. Dalam kasus ini, peserta didik di golongkan jenis kesulitan underachievers.

Peserta didik tidak memahami definisi bentuk logaritma, konsep Logaritma dan konsep prasyarat yang terkait logaritma, sehingga tidak mengerjakan soal terkait materi tersebut. Dalam hal ini peserta didik tidak dapat mencapai KKM (Kriteria Ketuntasan Minimal). Kasus peserta seperti ini di golongkan jenis lower group.

Kesulitan dalam berbicara dan berbahasa Inggris. Pembelajaran yang menggunakan pengantar bahasa Inggris membuat peserta didik sulit berkomunikasi dengan guru karena kurangnya kemampuan berbahasa Inggris yang dimiliki peserta didik.

Selain itu faktor-faktor yang menyebabkan peserta didik dan guru mengalami kesulitan dalam pembelajaran Matematika dengan pengantar bahasa Inggris pada materi pokok bentuk Logaritma antara lain: materi ajar yang sulit dan bentuk penyajian materi yang disampaikan guru membuat peserta didik kurang tertarik. Kurangnya penekanan materi dan penarikan kesimpulan. Motivasi peserta didik dalam mengerjakan tugas yang di berikan guru kurang. Kemampuan berbahasa Inggris yang kurang menyebabkan komunikasi antara guru dan peserta didik saat proses pembelajaran kurang tercipta. Selain itu cara belajar peserta didik yang tidak memahami konsep materi melainkan dengan menghafal rumus dan prosedur dalam menyelesaikan soal, kurangnya latihan-latihan soal yang dilakukan peserta didik. Kurangnya pemahaman peserta didik mengenai aspek prasyarat untuk materi pokok bentuk logaritma. Kesulitan dalam mengelola pembelajaran yang kreatif karena motivasi belajar perserta didik yang secara umum tergolong rendah. Kurangnya 
pengetahuan materi prasyarat yang dimiliki peserta didik membuat guru perlu mengulang kembali materi yang berhubungan dengan bentuk logaritma sehingga sulit dalam mengatur waktu untuk menyelesaikan materi tersebut. Dan kurangnya buku referensi bidang Matematika berbahasa inggris tinggkat Madrasah Aliyah yang bisa digunakan oleh guru Matematika.

\section{Rekomendasi}

Upaya-upaya

untuk

meminimalisasikan kesulitan yang dialami peserta didik dan guru dalam belajar Matematika dengan mengunakan pengantar bahasa Inggris pada materi logaritma antara lain guru di minta menekankan pemahaman konsep materi pokok bentuk logaritma, diharapkan adanya peningkatan kemampuan bahasa inggris yang dimiliki oleh guru dan peserta didik sehingga komunikasi saat proses pembelajaran berjalan dengan lancar. Selain itu, berdasarkan hasil penelitian yang telah dilakukan penulis mengemukakan bahwa pembelajaran Matematika dengan pengantar bahasa Inggris pada Materi Pokok Bentuk Logaritma Kelas $X \quad$ (CB) Bilingual Madrasah Aliyah Negeri 3 Palembang tahun pelajaran 2019/2020 membutuhkan perhatian besar dan kajian yang lebih dalam lagi. Sehingga pembelajaran Matematika dengan pengantar bahasa Inggris tidak menjadi masalah besar dalam pengembangan program biligual (CB) di madrasah sehingga program ini bisa menjadi icon bagi madrasah di masa depan yang dapat menghasilkan para alumni yang memiliki keterampilan berbahasa dengan baik yang memungkinkan mereka dapat bersaing di dunia kerja baik nasional maupun internasional.

Bagi peneliti selanjutnya diharapkan untuk dapat mengkaji lebih banyak sumber atau referensi yang terkait dengan kesulitan belajar Matematika dengan pengantar bahasa Inggris pada kelas bilingual program. 


\section{DAFTAR PUSTAKA}

Abdurahman, M. (2009). Pendidikan Bagi Murid Berkesulitan Belajar. Jakarta: PT. Rineka Cipta.

Ahmadi, A. \& Supriyono, W. (2013). Psikologi Belajar. Jakarta: PT. Rineka Cipta

Asmani, J, M. (2009). 7 Kompetensi Guru Menyenangkan dan Profesional.Jokjakarta: Power Book (IHDINA), 59

Budiyono. (2003). Metodologi Penelitian Pendidikan.Surakarta: Sebelas Maret University Press

Depdiknas. (2001). Kurikulum Berbasis Kompetensi Mata Pelajaran Matematika Sekolah Dasar.

Hamdani. (2011). Strategi Belajar Mengajar. Bandung: CV Pustaka Seti.a

Handayani, H (2015). Pengaruh Pembelajaran Kontektual Terhadap Kemampuan Pemahaman Representasi Matematika Siswa SD. Jurnal Pendidikan Guru Sekolah Dasar. I (1) : 142-149.

Hamalik, O. (1983). Matode Belajar dan Kesulitan-Kesulitan Belajar. Bandung: Tarsito.

Hollands, R. (2011). A Dictionary of Mathematics. Jakarta: Erlangga.

Djamarah,S. B.(2015). Psikologi Belajar.Jakarta: Rineka Cipta.

Kartini, K. (1985). Bimbingan Belajar di SMA danPerguruan Tinggi. Jakarta: Rajawali.

Lexy. J. Moleong. (2000). Metodologi Penelitian Kualitatif. Bandung: PT. Remaja Rosdakarya, 135.

Nana, S. S. (2009). Metode Penelitian Pendidikan. Bandung: PT. Remaja Rosdakarya.

Ngalimun, (2016). Strategi dan Model Pembelajaran. Yogyakarta: Aswaja Pressindo,2015. HIm.203.

Sugiyono. (2009). Metode Penelitian Pendidikan. Bandung: PT. Remaja Rosdakarya.

Susanto, A. (2013). Teori Belajar dan Pembelajaran di Sekolah Dasar. Jakarta: Kencana

Ulfa, F. (2017). Analisis Judul. Skripsi Fakultas Tarbiyah dan Keguruan Study Pendidikan Matematika UIN Alladdin Makasar, h. 23.

Yuqin, L., \& Xiuzhen, G. (2011), A Study on the Application of the Immersion Teaching Modell to EFL Learners in Institusion of Higher Learning. Diambil kembali dari, http://proquest. Umi.com /pqdweb. 